\title{
Relationship of Retrovirus Polyprotein Cleavages to Virion Maturation Studied with Temperature-Sensitive Murine Leukemia Virus Mutants
}

\author{
OWEN N. WITTE AND DAVID BALTIMORE* \\ Department of Biology and Center for Cancer Research, Massachusetts Institute of Technology, Cambridge, \\ Massachusetts 02139
}

Received for publication 3 January 1978

\begin{abstract}
Murine leukemia virus mutants ts3 (Moloney) and $t s 24$ (Rauscher) both formed late-budding structures on the cell membrane at restrictive temperature. They both accumulated core polyproteins $\operatorname{Pr} 65^{\text {gag }}$ and $\operatorname{Pr} 180^{\text {par-pol }}$ in cell membranes, but the envelope precursor was rapidly turned over. After shift to permissive temperature in the presence of cycloheximide, the accumulated precursors were sequentially cleaved via discrete intermediates both during the final stages of the budding process and in newly released virions to yield the finished virion core proteins and reverse transcriptase. The precursor form of reverse transcriptase was not enzymatically active and became activated partially or entirely inside released virions.
\end{abstract}

Three primary polypeptide translation products of the murine retrovirus genome have been defined. These are: (i) $\operatorname{Pr}^{\text {env }}$, an 80,000- to 90,000molecular-weight glycosylated precursor, translated on membrane-bound ribosomes $(2,6,12$, $17,18,34)$, that upon cleavage yields the virion envelope proteins gp70, p12E, and $\mathrm{p} 15 \mathrm{E}$; (ii) Pr65 ${ }^{\text {gaf }}$, a 65,000-molecular-weight precursor, encoded on cytoplasmic ribosomes and possibly derived from a larger $\operatorname{Pr} 75^{\text {pag }}$, that is cleaved to form the major internal virion protein, $\mathrm{p} 30$, and three other low-molecular-weight proteins $(4,10$, $27,29,30$ ); and (iii) $\operatorname{Pr} 180^{\text {gag-pol }}$, a polyprotein of estimated molecular weight 180,000 made in small quantities that contains both Pr65 ${ }^{\text {gag }}$ and the virion reverse transcriptase, $p 85 . \operatorname{Pr} 180^{\text {par-pol }}$ has been demonstrated both by in vitro translation using virion-derived 35S RNA as template and by in vivo labeling experiments $(1,11,13$, $19,20,23,24,30$ ).

The precise mechanisms by which these proteins or their cleavage products aggregate at the cell membrane to form the viral budding structure are unknown. The interrelationship of macromolecular assembly and specific proteolytic cleavage is difficult to assess in cells infected by wild-type virus because all stages of assembly and processing are occurring simultaneously. In this report we describe the processing of murine leukemia virus (MuLV) polyproteins in cells infected by temperature-sensitive $(t s)$ mutants Moloney ts3 (37) and Rauscher ts24 (28), both blocked at late stages of assembly. These mutants fail to cleave Pr65 ${ }^{\text {gag }}$ and Pr180 $0^{\text {gag-pol }}$ but not $\operatorname{Pr} 80-90^{e n v}$ at the restrictive temperature. The proteins all collect at the plasma membrane, and large numbers of late-stage budding structures are evident. Temperature shiftdown experiments in the presence of cycloheximide demonstrate that preformed Pr65 $5^{\text {gar }}$ and Pr180 $0^{\text {gag-pol }}$ can be cleaved. Cleavage of both precursors can be demonstrated in released virions and may also occur before release of buds from the cell. Enzymatically active reverse transcriptase is only demonstrable after cleavage. The genetic site of the primary defect in these mutants could not be ascertained from such experiments.

\section{MATERIALS AND METHODS}

Viruses and cells. MuLV Moloney strain ts3 (37) and Rauscher strain $t s 24$ (28) were gifts from P. Wong, University of Illinois, and S. Aaronson, National Cancer Institute (NCI), respectively. Both mutants were cloned upon arrival in this laboratory in a previously cloned line of NIH/3T3 fibroblasts. The ratio of virion budding at $32.5 / 39^{\circ} \mathrm{C}$ was 100 - to 500 -fold for $t s 3$ and 200 - to 1,000 -fold for $t s 24$ assayed by reverse transcriptase release; similar results were previously found using other cell lines infected by these mutants $(28,35$, 37). Cloned wild-type Moloney MuLV in NIH/3T3 fibroblasts has been previously described (7). Cell lines were maintained at $37^{\circ} \mathrm{C}$ for routine passage in Dulbecco-modified Eagle (DME) medium (Grand Island Biological Co.) with $10 \%$ calf serum.

Immune sera. Rabbit antisera to Moloney MuLV p30, gp70, and reverse transcriptase were prepared and characterized for specificity as previously described $(24,33)$. Goat antiserum to disrupted Moloney MuLV virions and purified p30 was received from $R$. Wilsnack, NCI. Antiserum from rats regressing a syn- 
geneic lymphoma induced by Gross-type MuLV (antiC58NTD) was a gift from I. Weissman, Stanford Medical School.

Metabolic labeling. Subconfluent cell monolayers (10-cm petri dishes, Falcon Plastics) were labeled with $2.5 \mathrm{ml}$ of $\left[{ }^{35} \mathrm{~S}\right.$ ] methionine (New England Nuclear Corp., Boston, Mass.) at $50 \mu \mathrm{Ci} / \mathrm{ml}$ in DME containing $1 / 50$ the normal methionine concentration or ${ }^{14} \mathrm{C}$-labeled mixed amino acids $(10 \mu \mathrm{Ci} / \mathrm{ml})$ in $D M E$ with $1 / 100$ the normal amino acid concentration, at the time and temperature indicated in the text. Cells were labeled with $\left[{ }^{32} \mathrm{P}\right]$ orthophosphate at $50 \mu \mathrm{Ci} / \mathrm{ml}$ in phosphatefree minimal essential medium as described in the text. In some experiments, cultures were shifted to permissive temperature $\left(32.5^{\circ} \mathrm{C}\right)$ in complete DME containing $50 \mu \mathrm{g}$ of cycloheximide per $\mathrm{ml}$. This concentration of cycloheximide decreased protein synthesis to 2 to $5 \%$ that of control cells.

Immunoprecipitation. All procedures for extraction and processing of immunoprecipitates were carried out at 0 to $4^{\circ} \mathrm{C}$. Cells were lysed, scraped into extraction buffer (1\% Triton X-100, $0.5 \%$ deoxycholate, $0.1 \%$ sodium dodecyl sulfate [SDS], $0.01 \mathrm{M} \mathrm{NaH}_{2} \mathrm{PO}_{4}$ $\mathrm{NaH}_{2} \mathrm{PO}_{4}, 0.1 \mathrm{M} \mathrm{NaCl}, \mathrm{pH} \mathrm{7.5)}$ at $1 \times 10^{6}$ to $2 \times 10^{6}$ cells $/ \mathrm{ml}$, and then clarified at $2,000 \times g$ for $15 \mathrm{~min}$. To preclear, extracts of 4 to $5 \mathrm{ml}$ were incubated overnight with $20 \mu \mathrm{l}$ of normal rabbit serum and $200 \mu \mathrm{l}$ of $10 \%$ (vol/vol) Formalin-fixed Staphylococcus aureus Cowen strain I (14) and then reclarified at 150,000 $\times$ $\mathrm{g}$ for $2 \mathrm{~h}$. This removed nonspecific adsorption to the immune adsorbent. Immune precipitates were made by incubating up to $1 \mathrm{ml}$ of extract with $5 \mu \mathrm{l}$ of immune serum overnight; $100 \mu$ l of a concentrated lysate $(2 \times$ $10^{7}$ cells $/ \mathrm{ml}$ ) of uninfected NIH cells clarified at 150 ,$000 \times g$ for $2 \mathrm{~h}$ was included to compete out normal cell constituents that might precipitate. $S$. aureus $(50$ $\mu \mathrm{l}$ of $10 \%$ [vol/vol] stock) was then added for $2 \mathrm{~h}$. The pellets were washed three times in lysis buffer and suspended for SDS-polyacrylamide gel electrophoresis in $1 \% \mathrm{SDS}, 1 \% 2$-mercaptoethanol, $50 \mathrm{mM}$ Tris, $\mathrm{pH}$ 6.8 , and $10 \%$ glycerol.

SDS-polyacrylamide gel electrophoresis. Linear 20 to $5 \%$ polyacrylamide gradient gels were prepared and used for electrophoresis as previously described $(15,34)$. Gels were fixed and processed for fluorography as previously described (5).

Reverse transcriptase. Reverse transcriptase was assayed with exogenous template and primer as previously described (22). Glycerol gradient centrifugation was as previously described (8).

Membrane fractionation. Total cell membranes were prepared by hypotonic swelling and Dounce homogenization as previously described $(9,34)$.

Electron microscopy. Cell monolayers were rapidly chilled to $0^{\circ} \mathrm{C}$, washed extensively with phosphate-buffered saline (PBS), fixed in situ for $2 \mathrm{~h}$ at $0^{\circ} \mathrm{C}$ with $2 \%$ buffered glutaraldehyde, washed with PBS, and then processed and embedded with graded alcohol dehydration. Sections cut perpendicular to the plane of growth were post-stained with uranyl acetate and lead citrate and viewed with a Philips EM201 electron microscope.

Virion protein and precursor nomenclature. The convention of August et al. (3) with modifications of the NCI Tumor Viral Immunology Workshop
(March 1977) for naming virion proteins, glycoproteins, phosphoproteins, and their precursors was followed. Molecular weights were estimated by comparison with standard protein markers (cytochrome $c$, immunoglobulin heavy and light chains, and bovine serum albumin) and known viral proteins of vesicular stomatitis virus and adenovirus 2 .

\section{RESULTS}

Morphological block in assembly of $t s 3$ and ts24. Cloned isolates of wild-type Moloney MuLV, $t s 3$ (Moloney), and $t s 24$ (Rauscher), all grown on the identical cell background, were examined by electron microscopy after growth at both permissive $\left(32.5^{\circ} \mathrm{C}\right)$ and restrictive $\left(39^{\circ} \mathrm{C}\right)$ temperatures. Cell monolayers were washed and then fixed in situ before dehydration. Sections were cut perpendicular to the plane of growth to allow for better orientation, as shown in a low-power view of a wild-type Moloney MuLV-infected cell (Fig. 1A). Wildtype virus-infected cells at either temperature or cells infected with $t s 3$ or $t s 24$ at $32.5^{\circ} \mathrm{C}$ contained budding structures in all stages of development, with an excess of apparently completed extracellular particles. Both $t s 3$ - and $t s 24$-infected cells grown at $39^{\circ} \mathrm{C}$ accumulated large numbers of late-budding structures as shown in Fig. 1B and 1D (36, 38). Early-budding forms (Fig. 1C) were seen at a much lower frequency in cells infected by both mutants (Table 1).

Polyprotein precursors. The MuLV genome is translated into three major polyproteins that are later cleaved to form the virion proteins $(4,11,18,27)$. To analyze the size and immune reactivity of the wild-type Moloney MuLV viral proteins, infected and uninfected NIH cells were labeled for $20 \mathrm{~min}$ with $\left[{ }^{35} \mathrm{~S}\right]$ methionine, and the labeled proteins were immunoprecipitated with antisera prepared to purified p30, gp70, and p85 (reverse transcriptase) or to whole virus. The individual immunoprecipitates were then analyzed by SDS-polyacrylamide gel electrophoresis and autoradiography (Fig. 2). Uninfected cells contained virtually no immunoprecipitable radioactive bands (Fig. 2, control). From infected cells, anti-p85 (reverse transcriptase) precipitated $\operatorname{Pr} 180^{\text {gax-pol }}$ (lane 2); anti-p30 precipitated Pr65 ${ }^{\text {par }}$ and a lesser amount of Pr75 $5^{\text {par }}$ and Pr180 gap-pol (lane 4); anti-gp70 precipitated Pr80 env (lane 3). The anti-whole-virus sera precipitated the three major precursors, and no other prominent bands were found (Fig. 2, lanes 5 and 6). During the 20-min labeling period, some gag cleavage products were produced including p30. No additional precursors were evident if ${ }^{14} \mathrm{C}$-labeled mixed amino acids were used to label cells (not shown). Only Pr65 $5^{\text {pas }}$ incorporated detectable ${ }^{32} \mathrm{P}$ after labeling of cells for 


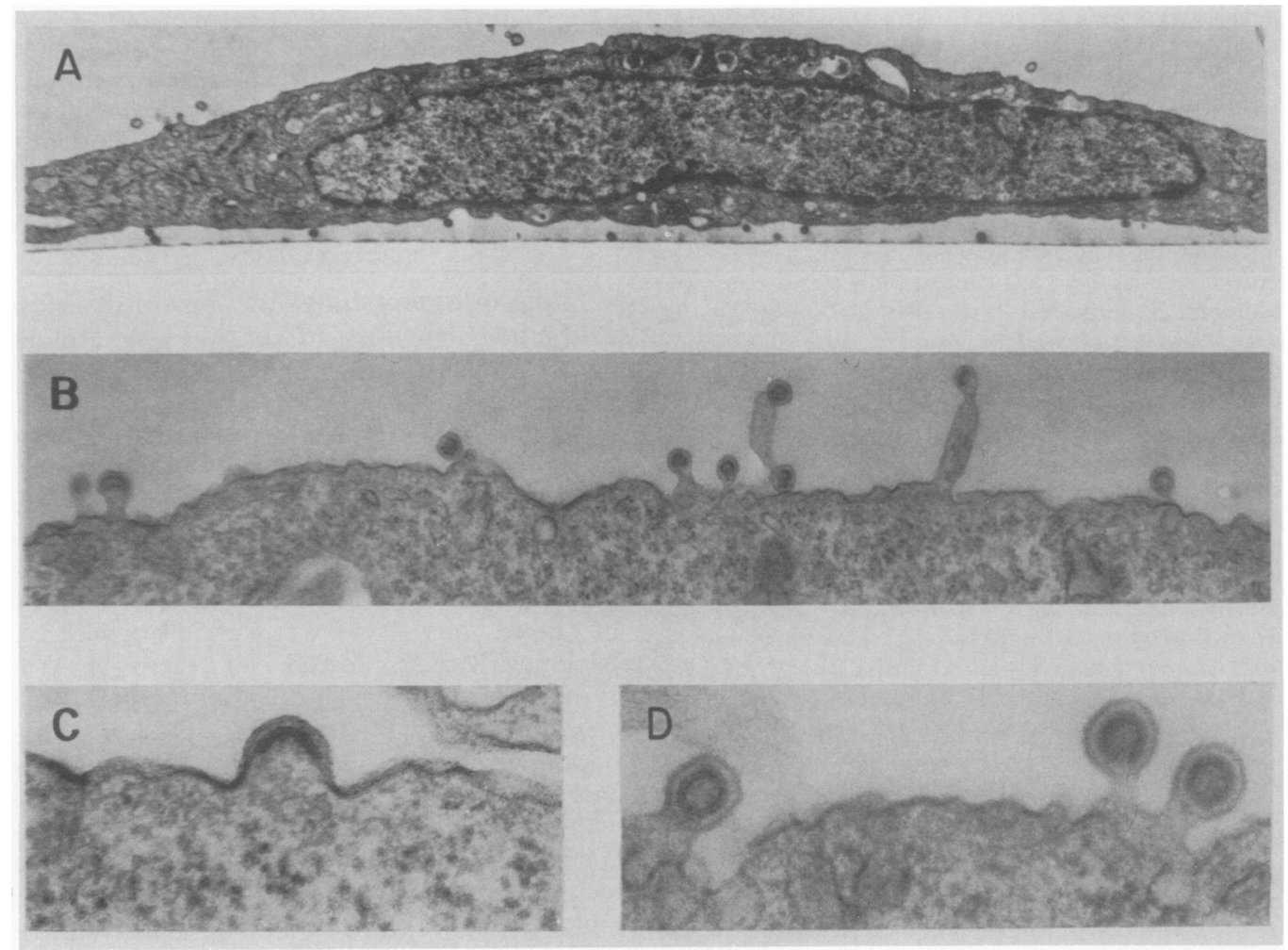

FIG. 1. Electron microscopy of wild-type MuLV and temperature-sensitive mutant-infected cells. Cloned isolates of wild-type Moloney, ts3 Moloney, and ts24 Rauscher MuLV in infected NIH/3T3 cells were grown at $32.5^{\circ} \mathrm{C}$ and then shifted to $39^{\circ} \mathrm{C}$ with fresh medium for $6 \mathrm{~h}$. Monolayers were then rapidly washed with icecold $P B S$, fixed in situ with glutaraldehyde-PBS at $0^{\circ} C$, and processed for electron microscopy. Sections cut perpendicular to the plane of the monolayer were used for better orientation. (A) Wild-type Moloney MuLV infected cell $(\times 5,000)$. Darkly stained extracellular virions are found both above and below the cell. (B) ts24 Rauscher MuLV infected cell membrane $(\times 20,000)$. Large numbers of late budding structures and fewer early budding forms and completed particles are seen. High-power $(\times 45,000)$ view of an early budding (C) and late (D) form from ts3 Moloney-infected cells.

20 min with ${ }^{32} \mathrm{PO}_{4}$ (Fig. 2).

Polypeptides of ts mutants. To analyze the polypeptides made by the $t s$ mutants, NIH cells infected with either $t s 3$ or $t s 24$ were grown at $32.5^{\circ} \mathrm{C}$, shifted to $39^{\circ} \mathrm{C}$, and immediately labeled for $2 \mathrm{~h}$ with either $\left[{ }^{35} \mathrm{~S}\right]$ methionine or ${ }^{32} \mathrm{PO}_{4}$ (Fig. 3 ). During such a long labeling period, wild-typeinfected cells showed extensive cleavage of the precursors (data not shown), but the mutantinfected cells showed mainly the three polyproteins $\operatorname{Pr} 180^{\text {gag-pol }}$, Pr65 ${ }^{\text {kag }}$, and Pr80 ${ }^{\text {ent }}$ or Pr90 $\operatorname{Pr}$. (Note that Moloney MuLV makes a Pr80 ${ }^{\text {en }}$ ' but Rauscher MuLV, wild type or mutant, makes a Pr90 ${ }^{\text {env }}$.) Immunoprecipitation of control, uninfected cells, in this experiment, showed a large number of immunoprecipitated bands with each of the antisera because the preclearing step used in other experiments was omitted for this experiment. A particular contaminant was the 190,000 to 200,000 band just above $\operatorname{Pr} 180^{\text {pag-pol }}$, which precipitated differently with each serum. This appears to be a normal cellular component, possibly the large external transformation-sensitive (LETS) protein. In spite of the background, each of the antisera precipitated the same polyprotein precursors as in the wild-type-infected, pulselabeled cells of Fig. 2, but very little of the cleavage products from the precursors could be seen. If $t s 24$-infected cells were labeled and then chased for 8 to $12 \mathrm{~h}$, slow cleavage of Pr65 ${ }^{\text {Rag }}$ to a 50,000 to 55,000 form was observed. This polypeptide is presumably similar to that described by Reynolds and Stephenson (25) in ts24-infected cells.

After labeling for $2 \mathrm{~h}$ with ${ }^{32} \mathrm{PO}_{4}$ for $t s 3$, only Pr65 ${ }^{\text {pag }}$ showed detectable label. For the Rauscher $t s 24$, both Pr65 and a slightly larger polypeptide (p70) were labeled. It is not clear whether this p70 represents a unique polypeptide or a heavily phosphorylated form of 
Pr65 $5^{\text {pag }}(16,26)$. Several other Rauscher stocks showed the same ${ }^{32} \mathrm{P}$-labeling pattern (not shown).

We further investigated the properties of precursors in $t s$ mutant-infected cells by cell fractionation studies. Membrane and cytosol frac-

TABLE 1. Electron microscopy of wild-type and temperature-sensitive mutants of $M u L V^{t}$

\begin{tabular}{cllc}
\hline \multirow{2}{*}{ Culture } & \multicolumn{2}{c}{$\begin{array}{c}\text { Median and range of MuLV budding } \\
\text { forms counted per cell section }\end{array}$} \\
\cline { 2 - 4 } & $\begin{array}{c}\text { Early } \\
\text { buds }\end{array}$ & Late buds & Particles \\
\hline $\begin{array}{c}\text { Uninfected } \\
\text { control }\end{array}$ & $0(0)$ & $0(0)$ & $0(0)$ \\
$\begin{array}{c}\text { Wild-type } \\
\text { Moloney }\end{array}$ & $1(0-3)$ & $2(1-6)$ & $14(5-23)$ \\
$\begin{array}{c}t s 3 \text { Moloney } \\
t s 24 \text { Rauscher }\end{array}$ & $2(1-5)$ & $20(12-34)$ & $3(1-7)$ \\
\hline
\end{tabular}

${ }^{a}$ All cultures were grown at $32.5^{\circ} \mathrm{C}$; then the medium was changed and the cultures were shifted to $39^{\circ} \mathrm{C}$ for $6 \mathrm{~h}$ before fixation and processing (see Materials and Methods). Sections from at least 10 cells were used for quantitation. tions were isolated from $t s 24$-infected cells labeled for $2 \mathrm{~h}$ at $39^{\circ} \mathrm{C}$. Almost all of the Pr65 Pr180 $0^{\text {gag-pol }}$, and Pr90 ${ }^{\text {env }}$ were associated with the membrane fraction (Fig. 4). Small amounts of $\mathrm{Pr}^{\mathrm{pol}}$ and $\mathrm{Pr}^{\mathrm{gag}}$ intermediates were seen, probably due to the occurrence of some processing during the multiple washing steps used to prepare the membrane preparation. Only after short pulse-labels (15 to $20 \mathrm{~min}$ ) could appreciable amounts of Pr65 ${ }^{\text {pag }}$ and Pr180 $0^{\text {gag-pol }}$ be isolated in the cytosol fraction. Pr $90^{\text {env }}$ was found in the membrane fraction after the shortest labels as previously reported (34). Similar results have been obtained for $t s 3$-infected cells (not shown).

Pulse-chase analysis was performed to monitor the stability and rate of cleavage of these polyproteins at restrictive temperature. Preliminary experiments demonstrated that $\mathrm{Pr} 65^{\text {pag }}$ labeled during a 20-min pulse was stable for periods of up to 4 to $6 \mathrm{~h}$ for both $t s 3$ and $t s 24$. The Pr80 env of $t s 3$ and $\operatorname{Pr} 90^{\text {env }}$ of $t s 24$ were found to turnover rapidly. A small fraction, though, was recovered as the defined cleavage products gp70 and $\mathrm{P} 12 \mathrm{E}, 15 \mathrm{E}$. This rapid degradation of

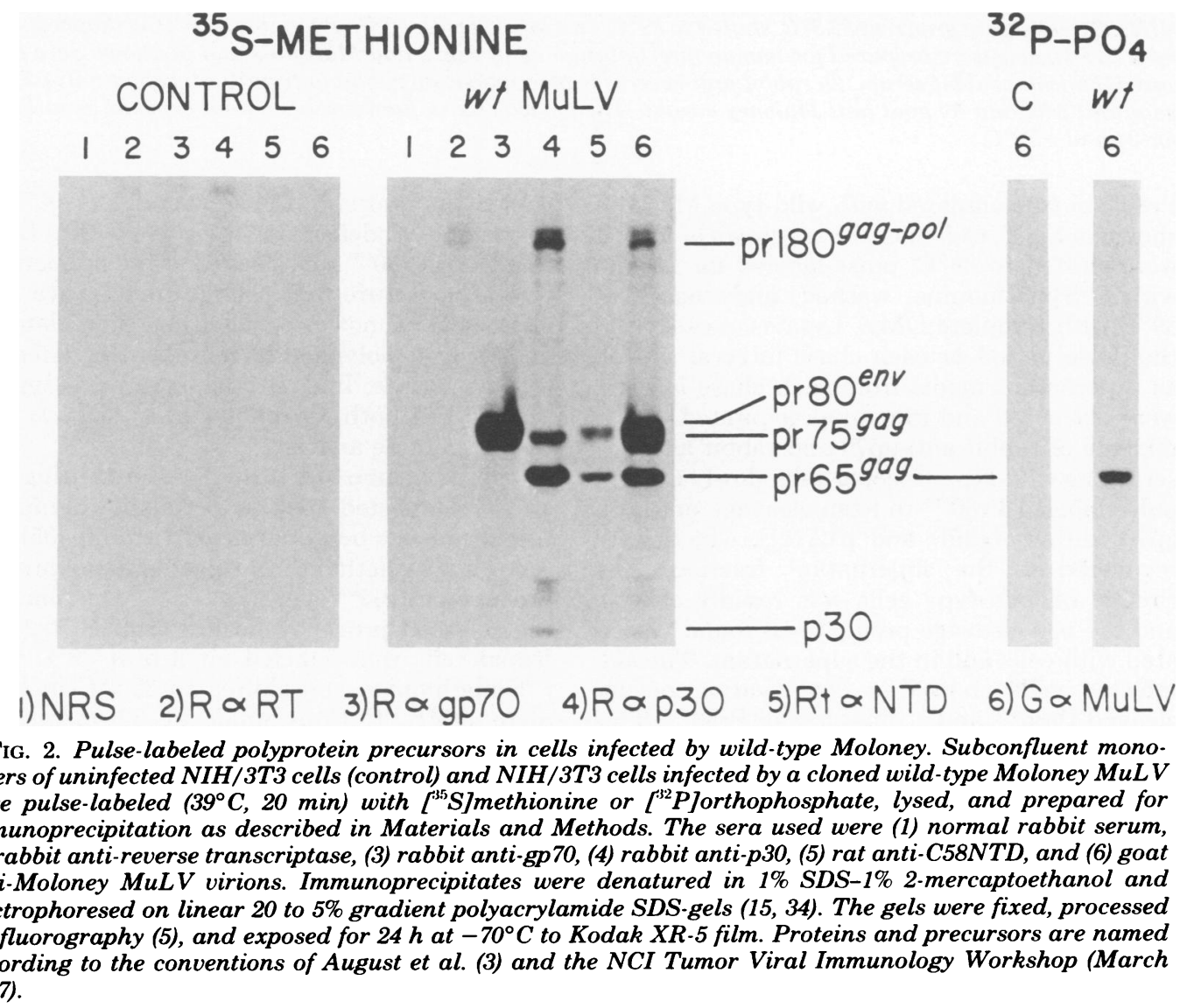




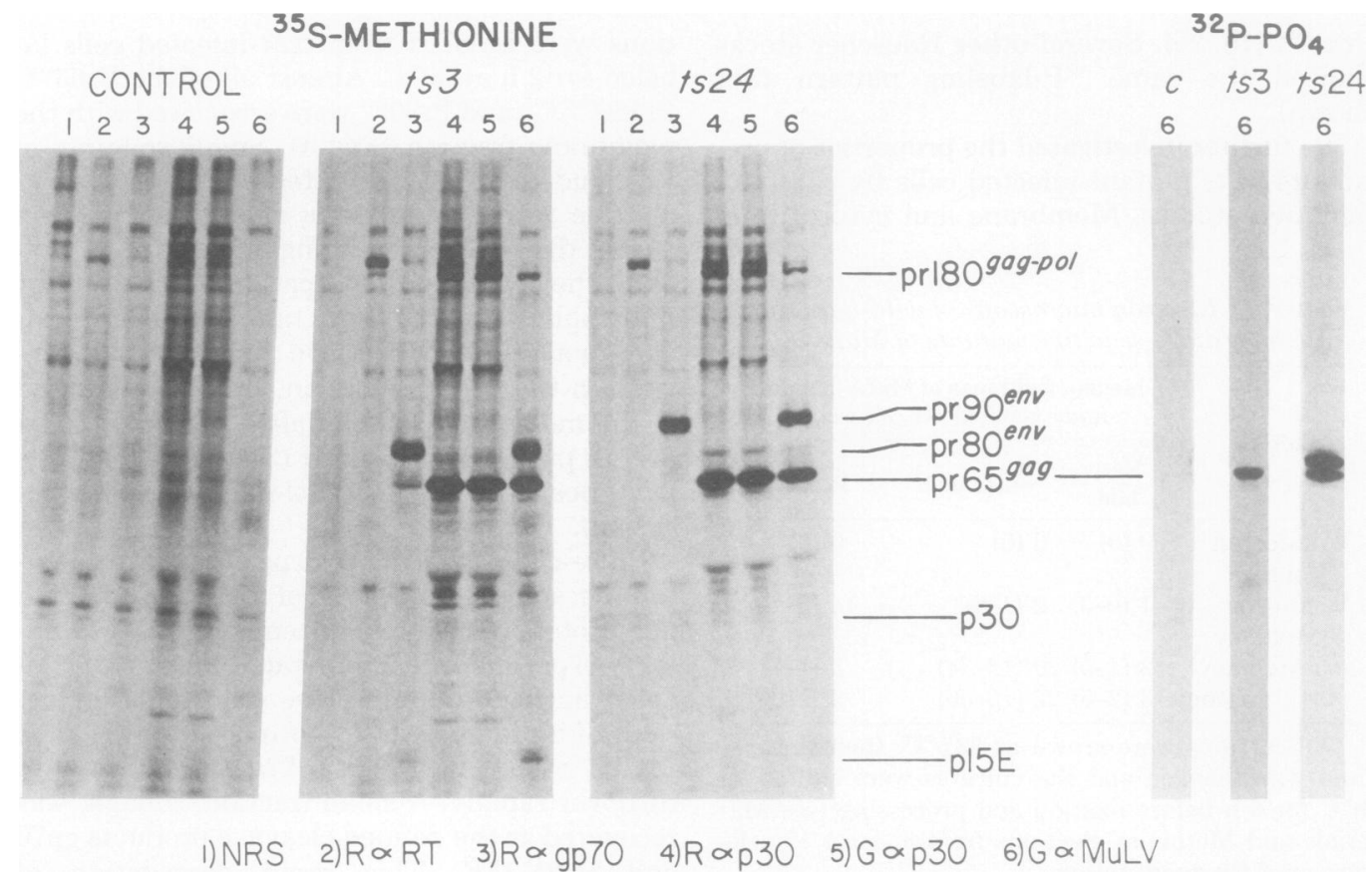

Fig. 3. Accumulation of polyprotein precursors in cells infected by ts3 and ts24. Control or infected NIH $/ 3 T 3$ cells were grown at $32.5^{\circ} \mathrm{C}$, shifted to $39^{\circ} \mathrm{C}$, and labeled with [ $^{35}$ S] methionine or [ ${ }^{32}$ P]orthophosphate for 2 h. Extracts were prepared for immunoprecipitation as in Fig. 2 and Materials and Methods. Sera used were (1) normal rabbit serum, (2) rabbit anti-reverse transcriptase, (3) rabbit anti-gp70, (4) rabbit anti-p30, (5) goat anti-p30, and (6) goat anti-Moloney virions. The gel was fixed, fluorographed, and exposed as in Fig. 2 for $24 h$ at $-70^{\circ} \mathrm{C}$.

Pr80 $0^{\text {en }}$ in $t s 3$ compared with wild-type MuLV is shown in Fig. 5. Cell monolayers grown at $32.5^{\circ} \mathrm{C}$ were shifted to $39^{\circ} \mathrm{C}$, pulse-labeled for $20 \mathrm{~min}$ with $\left[{ }^{35}\right.$ S $]$ methionine, washed, and chased at $39^{\circ} \mathrm{C}$ with complete DME. Lysates of cells from the pulse period or each chase interval as well as supernatant media from each chase interval were extracted and immunoprecipitated with a mixture of rabbit anti-gp70 and rabbit anti-p30 sera. The wild-type-infected cells slowly utilized pulse-labeled $\operatorname{Pr} 80^{\text {env }}$ to form cleavage products gp70 (diffuse band) and p12,15E, which were recovered in the supernatant fraction. The Pr65 ${ }^{\text {pag }}$ of wild-type cells was rapidly chased, and the p30 cleavage product was found associated with cells and in the supernatant. The $t s 3$ infected cells showed a conservation of uncleaved Pr65 ${ }^{\text {pas }}$ and a rapid loss of Pr80 ${ }^{\text {env }}$. This rapidly turning over Pr80 ${ }^{\text {env }}$ was not quantitatively converted to gp70-p15E. In some experiments a small fraction $(<10 \%)$ could be recovered as the appropriate cleavage products, but most $\operatorname{Pr} 80^{\text {env }}$ from $t s 3$ appeared to be degraded to unrecoverable products at restrictive temperature.

From the results, it appears that the two $t s$ mutants both show accumulation of core pre-

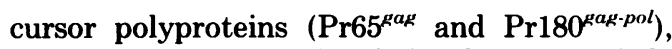
suggesting a defect in their cleavage. Little Pr80 ${ }^{e n}$ ' or Pr90 $90^{e n}$ ' was cleaved at the nonpermissive temperature, but a large fraction was degraded. It is not possible from such data to define what polypeptide contains the defect in these mutants, but $t s 3$ and $t s 24$ have similar phenotypes both morphologically (Fig. 1) and by polypeptide analysis.

Temperature shiftdown. After shifting $t s 3$ and $t s 24$-infected cells to permissive temperature, there is a burst of released virions (35). To investigate whether the intracellular polyprotein precursors Pr65 ${ }^{\text {gar }}$ and Pr180 18 fag-pol contribute to the released progeny and are cleaved, $t s 24$-infected cells were labeled for $2 \mathrm{~h}$ at $39^{\circ} \mathrm{C}$ with $\left[{ }^{35} \mathrm{~S}\right]$ methionine and shifted to $32.5^{\circ} \mathrm{C}$ in complete DME. Cycloheximide at $50 \mu \mathrm{g} / \mathrm{ml}$ was present after shiftdown to ensure that only premade polypeptides contributed to the yield. Both cell extracts and released particles were examined by specific immunoprecipitation and electrophoresis at various times after shiftdown.

Using anti-p85 (reverse transcriptase) serum, it was evident that in the cells and released virions, products other than $\operatorname{Pr} 180^{\text {gap-pol }}$ appeared after shiftdown (Fig. 6). In $20 \mathrm{~min}$, two 


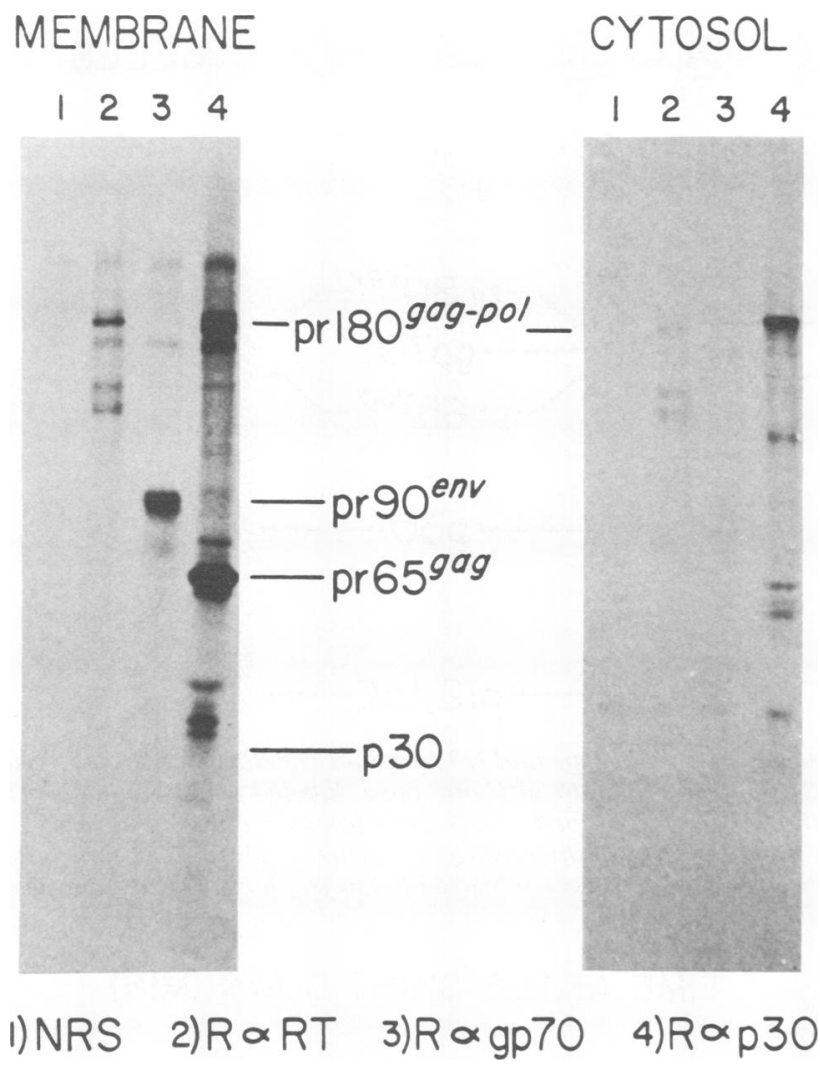

Fig. 4. Binding of precursor polyproteins to cellular membranes. Cells infected by ts24 grown at $32.5^{\circ} \mathrm{C}$ were shifted to $39^{\circ} \mathrm{C}$ and labeled for $2 \mathrm{~h}$ with $\left[{ }^{35} \mathrm{~S}\right]$ methionine. Monolayers were rapidly chilled at $0^{\circ} \mathrm{C}$, washed with iced saline, hypotonically swollen, and broken by homogenization with a Dounce homogenizer (9, 34). Nuclei and unbroken cells were removed at 1,000 $\times \mathrm{g}$ for $10 \mathrm{~min}$, and then membranes were pelleted at 40,000 $\times g$ for 25 min. Membranes and cytosol were prepared for extraction and immunoprecipitation. Sera used were (1) normal rabbit serum, (2) rabbit anti-reverse transcriptase, (3) rabbit anti-gp70, and (4) rabbit antip30. Samples were subjected to electrophoresis and fluorographed as in Fig. 2. The gel was exposed for 48 h.

labeled polypeptides, Pr140-145 ${ }^{\text {pol }}$ and Pr130 ${ }^{\text {pol }}$, became evident that were precipitated by antip85 but not by anti-p30. These presumably correspond to polypeptides called PrRT 1 and 2 by Jamjoom et al. (11). During longer chases of 40 and $60 \mathrm{~min}$, mature p85 was recovered in the supernatant virions, but only trace amounts were associated with the cells. Some Pr180 gag-pol was released before cleavage, as is more evident in Fig. 7. The high-molecular-weight band above Pr180 gag-pol is a cellular protein (or proteins) that apparently binds to the immune complexes.

The anti-p30 serum detected in both cells and virions a series of intermediate cleavage forms after shiftdown along with uncleaved precursors. In virions, p30 built up with time, whereas $\operatorname{Pr}^{\text {gag }}{ }^{\text {and }}$ ane intermediate $\operatorname{Pr} 40^{\text {gag }}$ remained evident throughout a 60 -min chase period.

The anti-gp70 serum detected mainly Pr90 in the cells over the $60 \mathrm{~min}$ after shiftdown. In the virions, however, only gp70 was recovered
(p15E and p12E were not included in these gels). In summary, the data of Fig. 6 show that after shiftdown, both Pr65 $5^{\text {gag }}$ and Pr180 gag-pol start to be cleaved and released into virions. Both uncleaved forms and intermediates were found in cells and in newly made particles. The final products, p30 and p85, build up with time in virions; p30 is maintained at a steady-state level in cells but p85 is not found in cells.

Some Pr65 $5^{\text {gag }}$ and Pr180 gag-pol were released from cells in uncleaved form after shiftdown. To determine whether these could be cleaved after release from cells, $t s 3$ virions harvested at 20 min after shiftdown to $32.5^{\circ} \mathrm{C}$ were incubated at permissive temperature in serum-free medium (Fig. 7). Pr65, Pr180, and Pr130 were all reduced by this incubation, and appearance of finished reverse transcriptase was evident. Reduction of the gag intermediates and increase of p30 also occurred. Addition of nonionic detergent inhibited all of the in vitro conversions. These 


\section{PULSE-CHASE (HR)}

Wt $\quad$ tS3

CELLS

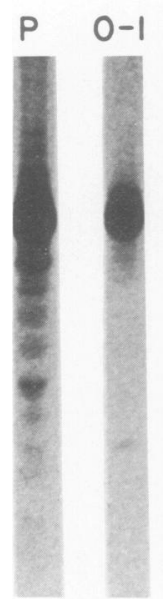

SUPERNATANTS
CELLS

SUPERNATANTS
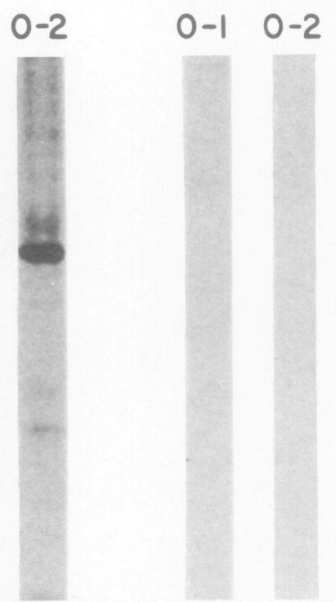

FIG. 5. Pulse-chase analysis of wild-type and ts3 core and envelope precursors. Wild-type-or ts3-infected monolayers grown at $32.5^{\circ} \mathrm{C}$ were shifted to $39^{\circ} \mathrm{C}$ and pulse-labeled for 20 min with $\left.~_{35}^{35} \mathrm{~S}\right]$ methionine, washed, and chased at $39^{\circ} \mathrm{C}$ with complete DME for 1 or $2 \mathrm{~h}$. Cells from the pulse period and each chase interval and the supernatant media from each chase interval were extracted and immunoprecipitated with a mixture of rabbit anti-p30 and anti-gp70. Samples were subjected to electrophoresis and fluorographed as in Fig. 2. The gel was exposed for $48 \mathrm{~h}$.
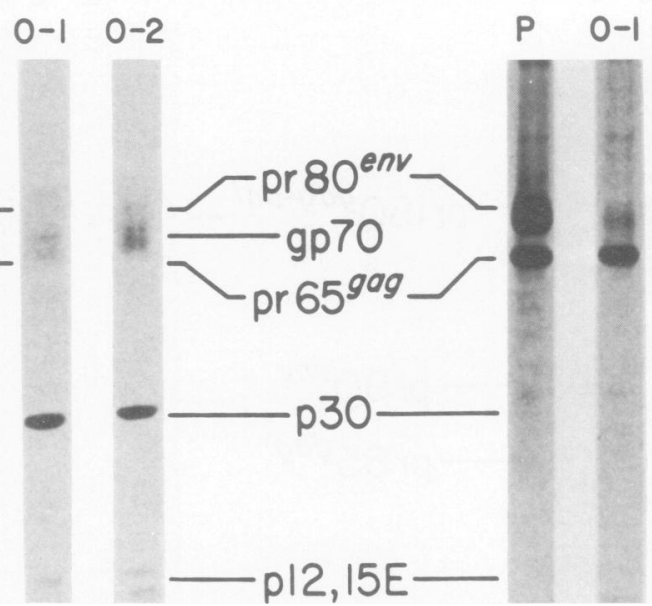

\section{TIME AFTER SHIFT DOWN (MIN)}

\section{CELLS}
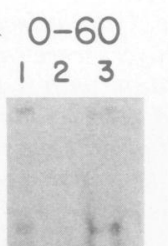

$-5$
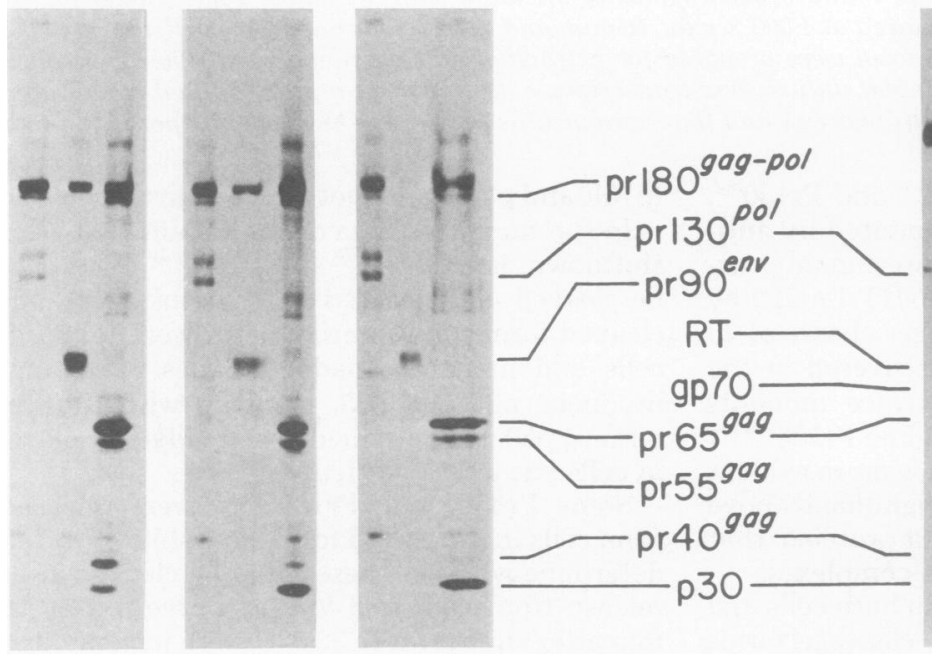

$$
\text { 1) } R \propto R T
$$

$$
\text { 2) } R \propto g p 70
$$

3) $R \propto p 30$

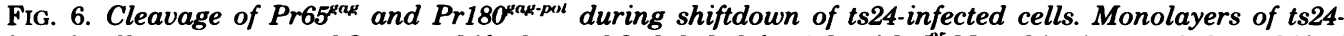
infected cells grown at $32.5^{\circ} \mathrm{C}$ were shifted to $39^{\circ} \mathrm{C}$, labeled for $2 \mathrm{~h}$ with ${ }^{35} \mathrm{~S}$ ]methionine, and then shifted down to $32.5^{\circ} \mathrm{C}$ in complete DME growth medium containing $50 \mu \mathrm{g}$ of cycloheximide per ml. Both cells and supernatant fluids were harvested and extracted at various intervals and then processed for immunoprecip. itation. Sera used were (1) rabbit anti-reverse transcriptase, (2) rabbit anti-gp70, and (3) rabbit anti-p30. Samples were subjected to electrophoresis and fluorographed as in Fig. 2. Cell extracts were exposed for 24 $h$, and supernatant fluid was exposed for $72 \mathrm{~h}$ at $-70^{\circ} \mathrm{C}$. 


\section{IN VITRO INCUBATION}

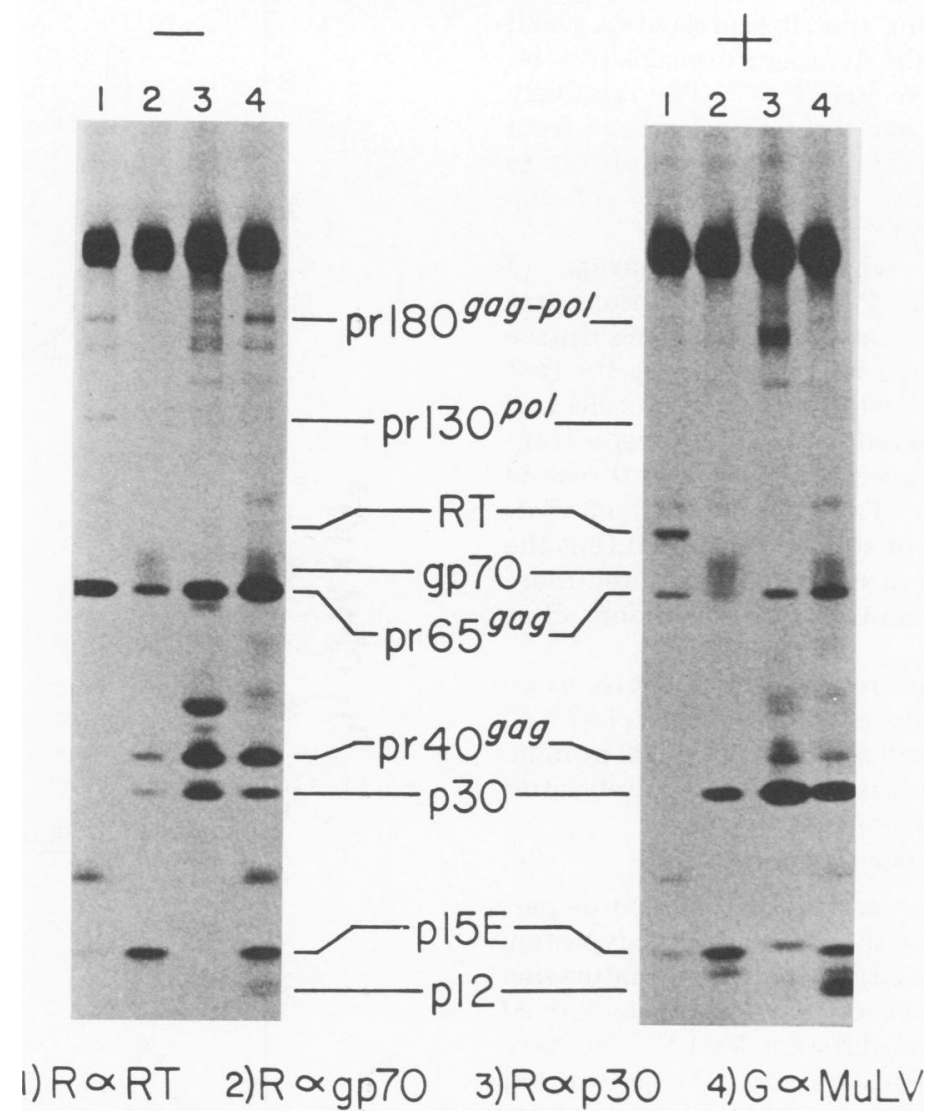

Fig. 7. In vitro processing of $\operatorname{Pr} 180^{\text {was.pol }}$ and $\operatorname{Pr} 65^{\text {pata }}$. Cells infected with ts 3 were grown at $32.5^{\circ} \mathrm{C}$, shifted to $39^{\circ} \mathrm{C}$, labeled for $2 \mathrm{~h}$ with $\left[^{35} \mathrm{~S}\right.$ ]methionine, and then shifted to $32.5^{\circ} \mathrm{C}$ in complete DME without serum containing $50 \mu \mathrm{g}$ of cycloheximide per ml. Supernatant fluid collected from 0 to 20 min after shiftdown was rapidly chilled to $0^{\circ} \mathrm{C}$ and clarified at $1,000 \times \mathrm{g}$ for $10 \mathrm{~min}$ to remove any cells or large debris. One portion was further incubated at $32.5^{\circ} \mathrm{C}$ for $20 \mathrm{~min}$, and then both were extracted for immunoprecipitation. Sera used were (1) rabbit anti-reverse transcriptase, (2) rabbit anti-gp70, (3) rabbit anti-p30, and (4) goat anti-Moloney virion. Samples were subjected to electrophoresis and fluorographed as in Fig. 2. The gel was exposed for 72 h.

supernatant precursors were presumably packaged into virions because they were in a particulate fraction and had a density between 1.14 and $1.17 \mathrm{~g} / \mathrm{ml}$ (unpublished observations).

Enzymatic acitvity of Pr180 ${ }^{\text {sag-pol }}$. Previous work has indicated that retrovirus-infected cells have little or no active intracellular reverse transcriptase (21). Cells infected by $t s 3$ or $t s 24$, however, build up $\operatorname{Pr} 180^{\text {gas-pol }}$, the precursor to reverse transcriptase at nonpermissive temperature. As shown above, the $\operatorname{Pr} 180^{\text {gag-pol }}$ is localized in cell membranes; therefore, to investigate whether Pr180 18 ag-pol is enzymatically active, the reverse transcriptase activity of membranes of cells infected with wild-type MuLV, $t s 3$, and $t s 24$ was studied (Table 2). Cells were also shifted to permissive temperature in the presence of cycloheximide to study release of reverse transcriptase. Membranes of $t s$ mutant-infected cells held at nonpermissive temperature had relatively little active enzyme. After shiftdown, enzyme activity in the membranes increased, and threefold more enzyme was released from the cells infected with $t s 3$ and $t s 24$ than from cells infected with wild-type virus (Table 2).

To investigate whether any of the enzyme activity found in membranes at nonpermissive temperature was Pr180 18 ar-pol, the size of the enzyme solubilized from membranes was investigated by glycerol gradient centrifugation (Fig. 8). The only defined peak of enzymatic activity was 85,000 in molecular weight (Fig. $8 \mathrm{C}$ ), like 
that of membranes from wild-type MuLV-infected cells (Fig. 8B) or the enzyme from virions (Fig. 8A), suggesting that it represents a small breakthrough of the temperature-sensitive lesions and not active $\operatorname{Pr} 180^{\text {gag-pol }}$. The relatively low incorporation and diffuse background from ts24 membranes (Fig. 8C) make it difficult to rule out some low specific activity of the Pr180 gag-pol or Pr $130^{\text {pol }}$ precursors.

To investigate whether the cleavage of Pr180 gag-pol and the $\mathrm{Pr}^{\text {pol }}$ forms in virions was paralleled by an increase of reverse transcriptase activity, virions were harvested during the first 15 min after shiftdown of $t s 3$-infected cells and then further incubated for $30 \mathrm{~min}$. Reverse transcriptase activity increased more than threefold during incubation (Table 3 ). Harvest of virus after 30 or 60 min of shiftdown showed that the threefold increase of enzyme represented more than another $15 \mathrm{~min}$ of collection time after shiftdown.

We conclude that reverse transcriptase as an active enzyme only appears when $\operatorname{Pr} 180^{\text {gag-pol }}$ has been cleaved to form the active p85 protein. This cleavage occurs mainly, if not entirely, after release of virions from cells.

\section{DISCUSSION}

Previous work on assembly of retrovirus particles had suggested that cleavage of polyprotein precursors was a late step in the maturation sequence $(29,38)$. Using two ts mutants derived independently from different MuLV's, we have confirmed this suggestion and have shown that the $t s$ lesion(s) retards two of three polyproteins

TABLE 2. Reverse transcriptase activity of cell membranes and virions from temperature-sensitive mutants

\begin{tabular}{|c|c|c|c|c|}
\hline \multirow[b]{2}{*}{ Source } & \multicolumn{4}{|c|}{$\mathrm{cpm} \times 10^{-3} / 10^{6 i}$ cells } \\
\hline & $\begin{array}{l}\text { Unin- } \\
\text { fected }\end{array}$ & $\begin{array}{l}\text { Wild } \\
\text { type }\end{array}$ & $t s 3$ & $t s 24$ \\
\hline $\begin{array}{l}\text { Cell membranes } \\
\text { harvested from } \\
\text { cells held at } 39^{\circ} \mathrm{C} \\
\text { for } 8 \mathrm{~h}\end{array}$ & $<1$ & 25.0 & 1.6 & 3.8 \\
\hline $\begin{array}{l}\text { Cell membranes } \\
\text { harvested from } \\
\text { cells shifted to } \\
32.5^{\circ} \mathrm{C} \text { for } 1 \mathrm{~h}^{a}\end{array}$ & $<1$ & 20.5 & 5.7 & 24.3 \\
\hline $\begin{array}{l}\text { Virions released } \\
\text { from cells during } \\
\text { 1-h shiftdown" }\end{array}$ & $<1$ & 34.0 & 110.0 & $\begin{array}{l}87.5 \\
\cdot\end{array}$ \\
\hline
\end{tabular}

"Cells held at $39^{\circ} \mathrm{C}$ were shifted to $32.5^{\circ} \mathrm{C}$ in fresh medium with $50 \mu \mathrm{g}$ of cycloheximide per $\mathrm{ml}$ for $1 \mathrm{~h}$, and then supernatant virions were pelleted. Total cell membranes pelleted after hypotonic swelling and Dounce homogenization $(9,34)$ were dissolved in 20 $\mathrm{mM}$ Tris, $\mathrm{pH}$ 8.3-1\% Nonidet P-40. Reverse transcriptase was measured with an exogenous template primer assay (22).

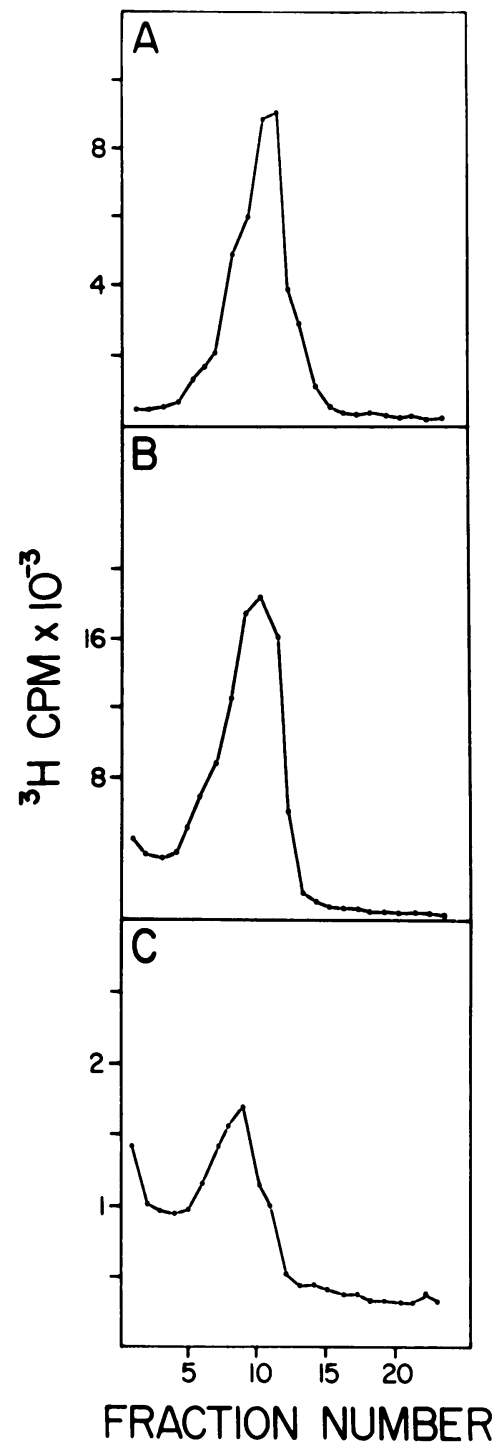

FIG. 8. Glycerol gradient analysis of reverse transcriptase. Cellular membranes or virion samples of $100 \mu \mathrm{l}$ were extracted in $1 \%$ Nonidet P.40 in $100 \mathrm{mM}$ $\mathrm{NaCl}, 10 \mathrm{mM}$ Tris, $\mathrm{pH}$ 7.5, $5 \mathrm{mM} \mathrm{MgCl}, 0.1 \mathrm{mM}$ EDTA, and $10 \mathrm{mM}$ dithiothreitol and layered on 5 $\mathrm{ml}$ of 40 to $20 \%$ glycerol gradients (SW50.1 rotor) containing the same buffer with $1 \%$ Nonidet P-40. Gradients were run at 45,000 rpm, $32 \mathrm{~h}, 4^{\circ} \mathrm{C}$. Fractions were assayed for reverse transcriptase by using an exogenous template primer assay (22). (A) Wildtype MuLV virions. (B) Cell membranes isolated by pelleting after hypotonic swelling and Dounce homogenization $(9,34)$ of $10^{6}$ wild-type $M u L V$-infected cells grown at $39^{\circ} \mathrm{C}$. (C) Cell membranes of $10^{6} \mathrm{ts} 24$ infected cells grown at $39^{\circ} \mathrm{C}$.

from cleaving. We have further been able to demonstrate that after shiftdown from restrictive temperature, preformed polypoteins are 
cleaved and that much of the cleavage takes place after release of virions from the cells.

Events of maturation. Although it is not evident from these data what is the precise genetic defect in $t s 3$ and $t s 24$, the mutants do reveal a crucial stage of the MuLV maturation sequence. Apparently, Pr65 $5^{\text {par }}$ and $\operatorname{Pr} 180^{\text {gar-pol, }}$ although made as soluble proteins, can migrate to the cell membrane and become organized in quite mature buds without proteolytic cleavage taking place. Presumably this is a normal stage in the MuLV budding process that has been "frozen" by the mutant function.

Both the $\mathrm{Pr}^{\text {gar }}$ and $\mathrm{Pr}^{\text {gar-pol }}$ proteins are potential candidates for having the mutational lesion in these mutants. In principle, either could be prevented from a normal rate of cleavage by a mutation and thus block maturation.

The behavior of $\mathrm{Pr}^{\text {env }}$ in these mutants is less evident. It is much more unstable than the $\mathrm{Pr}^{\text {env }}$ of wild-type virus, and much of it degrades to unrecoverable products within an hour of its synthesis at nonpermissive temperature (Fig. 5). It is possible that the mutations are in the $\mathrm{Pr}^{\text {env }}$ gene and gave rise to the instability of the protein.

Because the precursor proteins labeled at nonpermissive temperature can be cleaved to their normal products after shiftdown, there is no irremedial defect in the MuLV proteins caused by the $t s$ lesion. This fact has allowed us to demonstrate that $\operatorname{Pr}^{\text {par }}$ cleavage can occur concomitant with the last budding stage and also in released virions. Pr180 aag-pol can be cleaved to Pr130 ${ }^{\text {pol }}$ while buds are still cell associated, but cleavage to p85 occurs only after release of particles from the cell surface. We believe that these events occur during normal budding in the same order because Jamjoom et al. (11) showed that both Pr65 ${ }^{\text {gag }}$ and Pr180 gag-pol cleavage are late events of the MuLV budding process. Opperman et al. (20) also showed for Rous sarcoma virus that $\operatorname{Pr} 180^{\text {oag-pol }}$ is cleaved in particles.

The fact that Pr65 ${ }^{\text {gag }}$ and $\operatorname{Pr} 180^{\text {gag-pol }}$ can be cleaved inside released virions incubated in the absence of serum or cells suggests that a protease is packaged in virions. Recent reports consistent with this idea have appeared $(32,39)$. Yoshinaka and Luftig (39) found that cleavage of Pr65 (they called it P70) required detergent treatment; we found that detergent inhibited cleavage. The times of incubation and concentrations were very different in the two experiments, and it seems likely that our conditions favor intravirion events, whereas their conditions allowed study of intervirion transfer of proteolytic factors.

Functional reverse transcriptase. It has previously been shown that infected cells make about 1 molecule of $\operatorname{Pr} 180^{\text {gaz-pol }}$ for each 25 to 50
TABLE 3. In vitro virion-bound generation of reverse transcriptase

\begin{tabular}{ccc}
\hline $\begin{array}{c}\text { Time of collection } \\
\text { after shiftdown } \\
(\text { min) }\end{array}$ & $\begin{array}{c}\text { cpm } \times 10^{-3} \text { incor- } \\
\text { porated }\end{array}$ & $\begin{array}{c}+30 \text { min cell-free } \\
\text { incubation }\end{array}$ \\
\hline $0-15$ & 14.2 & 47.5 \\
$0-30$ & 32.2 & - \\
$0-60$ & 80.3 & - \\
\hline
\end{tabular}

${ }^{a}$ Cultures of $t s 3$-infected NIH cells held at $39^{\circ} \mathrm{C}$ for $6 \mathrm{~h}$ were fed with serum-free DME containing $50 \mu \mathrm{g}$ of cycloheximide per $\mathrm{ml}$ and shifted to $32.5^{\circ} \mathrm{C}$ for the indicated times. Supernatants were rapidly chilled to $0^{\circ} \mathrm{C}$ and clarified at $2,000 \times \mathrm{g}$ for $15 \mathrm{~min}$, and then virus was pelleted at $100,000 \times g$ for $60 \mathrm{~min}$. One sample was reincubated for $30 \mathrm{~min}$ at $32.5^{\circ} \mathrm{C}$ before pelleting. Virus pellets were assayed for reverse transcriptase by an exogenous template - primer assay (22).

molecules of $\operatorname{Pr}^{\text {par }}(11,20)$. Both polypeptides appear to be initiated at the same place on a $35 \mathrm{~S}$ mRNA. A readthrough from gag to pol is controlled by some mechanism that bypasses a UAG termination codon (24). The present studies indicate that Pr180 gaf-pol is enzymatically inactive. Because it is localized in membranes, it was possible to assay it independently of inhibitory factors that are present in the cytosol (21). Although Pr180 gag-pol built up in membranes at restrictive temperature, very little reverse transcriptase was found in membranes compared to what could be released by shiftdown in the presence of cycloheximide (Table 2). Although a small amount of active 85,000-molecular-weight reverse transcriptase was found in membranes, no peak of active 180,000 or 130,000 form was found. Because appearance of active reverse transcriptase requires shiftdown and because reverse transcriptase activity increases after virions are released from cells (Table 3 ) - at the same time that p85 is cleaved from Pr130 $13{ }^{\text {pol }}$-it appears that active reverse transcriptase is only made inside of released, newly made virions.

A mechanism that assures activation of functional reverse transcriptase in virions will prevent premature initiation of reverse transcription before infection. The ability to detect formation of the first internucleotide bond in activated virions (31) had previously suggested that functional enzyme might only appear after virion maturation is complete.

It seems likely that Pr180 nascent buds through its Pr65 $5^{\text {par }}$ portion; it would therefore aggregate into the nascent bud just like any Pr65 molecule, but would carry reverse transcriptase into the bud with the Pr65 moiety. The enzyme would then be cleaved off when the protease activity that cleaves Pr65 was activated. What Pr130 contains that is lacking in the p85 is unclear. 


\section{ACKNOWLEDGMENTS}

We thank Claire Moore for performing the electron microscopy and Michael Paskind for excellent photographic work.

This research was supported by American Cancer Society grant VC-4I, Public Health Service grant CA-14051 from the National Cancer Institute, and a contract from the Virus Cancer Program of the National Cancer Institute. O.N.W. is a Helen Hay Whitney Foundation postdoctoral fellow. D.B. is an American Cancer Society Professor of Microbiology.

\section{LITERATURE CITED}

1. Arcement, L. J., W. L. Karshin, R. B. Naso, and R. B. Arlinghaus. 1977. gag polyprotein precursors of Rauscher murine leukemia virus. Virology 81:284-297.

2. Arcement, L. J., W. L. Karshin, R. B. Naso, G. Jamjoom, and R. B. Arlinghaus. 1976. Biosynthesis of Rauscher leukemia virus proteins: presence of p30 and envelope p.15 sequences in precursor polypeptides. Virology 69:763-774.

3. August, J. T., D. P. Bolognesi, E. Fleissner, R. V. Gilden, and R. Nowinski. 1974. A proposed nomenclature for the virion proteins of oncogenic RNA virus. Virology 60:595-601.

4. Barbacid, M., J. R. Stephenson, and S. A. Aaronson. 1976. gag gene of mammalian type-C RNA tumor viruses. Nature (London) 262:554-559.

5. Bonnar, W. M., and R. A. Laskey. 1974. A film detection method for tritium-labeled proteins and nucleic acids in polyacrylamide gels. Eur. J. Biochem. 46:83-88.

6. Famulari, N. G., D. L. Buchhogen, H.-D. Klenk, and E. Flessner. 1976. Presence of murine leukemia virus envelope proteins gp70 and $\mathrm{p} 15 \mathrm{E}$ in a common polyprotein of infected cells. J. Virol. 20:501-508.

7. Fan, H., and M. Paskind. 1974. Measurement of the sequence complexity of cloned Moloney murine leukemia virus 60-70S RNA: evidence for a haploid genome. J. Virol. 14:421-429.

8. Haseltine, W. A., A. Panet, D. Smoler, D. Baltimore, G. Peters, F. Harada, and J. E. Dahlberg. 1977. Interaction of tryptophan tRNA and avian myeloblastosis virus reverse transcriptase: further characterization of the binding reaction. Biochemistry 16:2625-2632.

9. Hay, A. J. 1974. Studies on the formation of the influenza virus envelope. Virology 60:398-418.

10. Jamjoom, G., W. L. Karshin, R. B. Naso, L. J. Arcement, and R. B. Arlinghaus. 1975. Proteins of Rauscher murine leukemia virus: resolution of a 70,000 dalton, non-glycosylated polypeptide containing p30 peptide sequences. Virology 68:135-145.

11. Jamjoom, G. A., R. B. Naso, and R. B. Arlinghaus. 1977. Further characterization of intracellular precursor polyproteins of Rauscher leukemia virus. Virology 78:11-34.

12. Karshin, W. L., L. J. Arcement, R. B. Naso, and R. B. Arlinghaus. 1977. Common precursor for Rauscher leukemia virus for gp69/71, p15E, and p12E. J. Virol. 23:787-798.

13. Kerr, I. M., U. Olshevsky, H. Lodish, and D. Baltimore. 1977. Translation of murine leukemia virus RNA in cell-free systems from animal cells. J. Virol. 18:627-635.

14. Kessler, S. W. 1975. Rapid isolation of antigens from cells with a staphylococcal protein A-antibody adsorbent. J. Immunol. 115:1617-1624.

15. Laemmli, U. K. 1970 . Cleavage of structural proteins during the assembly of the head of bacteriophage T4. Nature (London) 227:680-685.

16. Lamb, R. A., and R. W. Choppin. 1977. The synthesis of Sendai virus polypeptides in infected cells III. Phosphorylation of polypeptides. Virology 81:383-397.
17. Leamnson, R. N., H. M. Shander, and M. S. Halpern. 1977. A structural protein in Moloney leukemia virus. Virology 76:437-439.

18. Naso, R. B., L. J. Arcement, W. L. Karshin, G. A. Jamjoom, and R. B. Arlinghaus. 1976. A fucosedeficient glycoprotein precursor to Rauscher leukemia virus gp69,71. Proc. Natl. Acad. Sci. U.S.A. 73: 2326-2330.

19. Naso, R. B., L. J. Arcement, T. G. Wood, and R. Arlinghaus. 1975. The cell-free translation of Rauscher leukemia virus RNA into high molecular weight polypeptides. Biochim. Biophys. Acta 383:195-206.

20. Oppermann, H., J. M. Bishop, H. E. Varmus, and L. Levintow. 1977. A joint product of the genes gag and pol of avian sarcoma virus: a possible precursor of reverse transcriptase. Cell 12:993-1005.

21. Panet, A., D. Baltimore, and H. Hanafusa. 1975. Quantitation of avian RNA tumor virus reverse transcriptase by radioimmunoassay. J. Virol. 16:146-152.

22. Paskind, M. P., R. A. Weinberg, and D. Baltimore. 1975. Dependence of Moloney murine leukemia virus production on cell growth. Virology 67:242-248.

23. Paterson, B., D. J. Marciani, and T. S. Papas. Cellfree synthesis of the precursor polypeptide for avian myeloblastosis virus DNA polymerase. Proc. Natl. Acad. Sci. U.S.A. 74:4951-4954.

24. Philipson, L., P. Andersson, U. Olshevsky, R. Weinberg, D. Baltimore, and R. Gesteland. 1978. Translation of murine leukemia and sarcoma virus RNAs in nuclease-treated reticulocyte extracts: enhancement of the gag-pol polypeptide with yeast suppressor tRNA. Cell 13:189-199.

25. Reynolds, R. K., and J. R. Stephenson. 1977. Intracistronic mapping of the murine type $\mathrm{C}$ viral gag gene by use of conditional lethal replication mutants. Virology 81:328-340.

26. Sen, A., C. J. Sherr, and G. J. Todaro. 1977. Phosphorylation of murine type $\mathrm{C}$ viral p12 proteins regulates their extent of binding to the homologous viral RNA. Cell 10:489-496

27. Shapiro, S. Z., M. Strand, and J. T. August. 1976. High molecular weight precursor polypeptides to structura proteins of Rauscher murine leukemia virus. J. Mol. Biol. 107:459-477.

28. Stephenson, J. R., and S. A. Aaronson. 1973. Characterization of temperature-sensitive mutants of murine leukemia virus. Virology 54:53-59.

29. Stephenson, J. R., S. R. Tronick, and S. A. Aaronson. 1975. Murine leukemia virus mutants with temperaturesensitive defects in precursor polypeptide cleavage. Cell 6:543-548.

30. Van Zaane, D., A. Dekker-Michielson, and H. P. J. Bloemers. 1976. Virus specific precursor polypeptides in cells infected with Rauscher leukemia virus: synthe sis, identification and processing. Virology 75:113-129.

31. Verma, I. M., N. L. Meuth, and D. Baltimore. 1972. The covalent linkage between RNA primer and DNA product of the avian myeloblastosis virus DNA polymerase. J. Virol. 10:622-627.

32. Von der Helm, K. 1977. Cleavage of Rous sarcoma viral polypeptide precursor into internal structural proteins in vitro involves viral protein p15. Proc. Natl. Acad. Sci. U.S.A. 74:911-915.

33. Witte, O. N., and D. Baltimore. 1977. Mechanism of formation of pseudotypes between vesicular stomatitis virus and murine leukemia virus. Cell 11:503-511.

34. Witte, O. N., A. Tsukamoto-Adey, and I. L. Weissman. 1977. Cellular maturation of oncornavirus glycoproteins: topological arrangement of precursor and product forms in cellular membranes. Virology 76:539-553.

35. Wong, P. K. Y., and J. A. McCarter. 1974. Studies of two temperature sensitive mutants of Moloney murine 
leukemia virus. Virology 58:396-408.

36. Wong, P. K. Y., and R. MacLeod. 1975. Studies on the budding process of a temperature-sensitive mutant of murine leukemia virus with a scanning electron microscope. J. Virol. 16:434-442.

37. Wong, P. K. Y., L. J. Russ, and J. A. McCarter. 1973 Rapid, selective procedure for isolation of spontaneous temperature-sensitive mutants of Moloney leukemia virus. Virology 51:424-431.

38. Yeger, H., V. I. Kalnins, and J. R. Stephenson. 1976. Electron microscopy of mammalian type C RNA viruses: use of conditional lethal mutants in studies of virion maturation and assembly. Virology 74:459-469.

39. Yoshinaka, Y., and R. B. Luftig. 1977. Properties of a P70 proteolytic factor of murine leukemia virus. Cell 12:709-719. 